\title{
A KLÍMA VÁLTOZÁSA KIMUTATHATÓ AZ ORSZÁGOS ERDŐÁLLOMÁNY ADATTÁR KLIIMA-KATEGÓRIÁIBAN
}

\author{
Kottek Péter és Király Éva \\ Nemzeti Földügyi Központ, Erdészeti Főosztály
}

\begin{abstract}
Kivonat
Az erdőrészletek klíma szerinti besorolása az Országos Erdőállomány Adattárban (OEA) kimutathatóan megváltozott az 1997-2006 és 2007-2016 periódusok között. A klímabesorolás változásait 1 hektár felbontású szabályos rácsháló pontjaiban vizsgáltuk, ami lehetővé tette a klímakategóriák országos szintü összehasonlitását és a két periódus között észlelhető változások részletes leírását annak ellenére, hogy az OEA-ban az erdörészletek a két időpontban nem teljes körüen feleltethetőek meg egymásnak. A rácsháló alkalmazása statisztikailag is könnyebben kezelhető eredményeket ad.

Eredményeink azt mutatják, hogy a klíma-besorolás 10 év alatt az erdőterület 5,4\%-án változott meg, és a klímakategóriák eloszlása az OEA 2006-ra és 2016-ra vonatkozó statisztikai állapotai között szignifikánsan különbözik. E szerint a klímaváltozás tetten érhető az igazgatási nyilvántartásban is. A változás gyorsnak mondható, az elmozdulások iránya pedig a jövőre nézve figyelmeztető, mivel azok általában kedvezőtlenek.

A 2006-ban még erdő, de 2016-ra eltünt, már nem-erdő rácspontok 44\%-a az erdőssztyepp klímába tartozott, azaz e klímakategóriába tartozó faállományok nagyobb eséllyel szünnek meg. Ugyanakkor az újonnan létrehozott erdőterületek legnagyobb része is erdőssztyepp (37\%) vagy cseres ill. kocsánytalan-tölgyes (34\%) klímában jött létre, tehát az új erdőket is száraz körülmények között létesítettük.
\end{abstract}

Kulcsszavak: klímaváltozás, erdészeti klímaosztályozás, Országos Erdőállomány Adattár, országos léptékủ rácsos mintavétel.

\section{CLIMATE CHANGE CAN BE DETECTED IN THE NATIONAL FORESTRY DATABASE}

\begin{abstract}
From 2006 to 2016 a noticeable change can be observed in the climatic classification of forest stands in the National Forestry Database (NFD). As the polygons of forest stands cannot be fully matched between the 2006 and 2016 state of the NFD, climate transitions were studied along a one hectare resolution sample grid. This sampling pattern allowed large scale comparison of climatic categories and the description of local changes occurred between the two periods (2006 state of NFD consists of field surveys between 1996 and 2005; 2016 state between 2005-2015 accordingly). The sample grid also facilitated the statistical evaluation.

The results show that climate classification has changed in 5.4 percent of the forest area, and the distribution of climate categories in 2016 shows a statistically significant difference compared to the 2006 state. Accordingly, the concept of climate change is strongly supported by data of the official forest inventory. The speed of climate shifts may be considered fast and the direction is warning as changes are generally unfavourable.

We also analysed the sampling grid nodes where the forest land use changed to another land use type between 2006 and 2016. We found that 44 percent of these sampling points were in the "forest steppe" climate category (the most arid one of
\end{abstract}


the 4 possible classes). This shows that in forest stands under this climate category land use change is more likely to be undertaken.

On the other hand the major part of newly afforested area is under "forest steppe" (37\%) and "sessile oak - Turkey oak" $(34 \%)$ climate which shows that new forests are planted under dry conditions.

Keywords: climate change, climate classification in forestry, National Forestry Database, large scale grid sampling.

\section{BEVEZETÉS}

Európa szerte számos kutatási eredmény mutat rá a klímaváltozás erdőkre gyakorolt hatásaira (Milad et al 2011). A fontos állományalkotó fafajok elterjedési területének északabbra húzódása már napjainkban is megfigyelhető (Honnay et al 2002, Milad et al 2011, SánchezSalguero et al 2012) és a jövöben még kifejezettebb lehet (Thurm et al 2018), hiszen a szárazsági elterjedési határ közelében található faállományok különösen érzékenyek a klímaváltozással gyakran együtt járó szárazodás hatásaira (Sánchez-Salguero et al 2012, Lindner et al 2014).

Az egyes erdőzónák, illetve fafajok déli/síkvidéki elterjedési határát elsődlegesen a nyári szárazsági stressz határozza meg, amely egyben a zárt erdők alsó elterjedési határát is kijelöli az erdőssztyepp felé (Mátyás et al 2009, Mátyás et al 2010a). A szárazsági határ Magyarországon döntő jelentőségü, mert minden fontosabb fafaj esetében kimutatható (Mátyás et al 2010a). A klímaváltozás jelenleg hazánkban megmutatkozó hatásairól több tanulmány tudósít. Csóka et al (2007), Csóka et al (2009), Berki et al (2014), Berki et al (2016), Berki (2017), Csóka \& Hirka (2017) és még sokan mások szerint a szárazodás hatásai már napjainkban is kimutathatók. Mátyás és munkatársai pedig a szárazsági elterjedési határ visszahúzódásáról számolnak be (Mátyás 2010, Mátyás et al 2010b, Mátyás et al 2017).

Az Országos Erdőkár Nyilvántartási Rendszerben rögzített aszálykárok mennyisége az 1962-2011 közötti 50 évben növekvő tendenciát mutat (Hirka et al 2018, Hirka 2017). Berki et al (2018) szerint a száraz alföldperemi, dombsági tájakon a gyakoribbá és hosszabbá vált aszályok hatására jelentős fapusztulás figyelhető meg, drasztikusan csökkent az állományok sürüsége, és jelentős élőfakészlethiány alakult ki.

A hazai erdészeti gyakorlat a termőhelyértékelés során eddig 4 klíma-kategóriát használt: a bükköst (B), a gyertyányos-tölgyest (GY-T), a kocsánytalan tölgyest ill. cserest (KTTCS) és az erdőssztyepp (ESZTY) (Járó 1972, Führer 2010, Führer et al 2011, a klímakategóriák részletes leírásáért lásd pl. Führer 2018). A klímaváltozás hatására új kategória bevezetése is szükséges lesz, amit sztyepp (SZTYEP) névvel fogunk illetni (Führer et al 2017a). Czúcz et al (2013) szerint 2050-re a bükk hazai zonális elterjedésének 56-99\%-a, a kocsánytalan tölgynek pedig 82-100\%-a az optimális klímatéren kívül lesz. Gálos \& Führer (2018) az egyes erdészeti klímaosztályok területének várható elörejelzése tekintetében, mértékében ugyan más, de hasonló tendenciákat jeleznek elöre. Becslésük szerint a 21. 
század közepére az ország területének több mint 10\%-a lehet sztyepp klímájú. Ezzel összhangban a várható ökonómiai változások is jelentősek lehetnek (Führer 2013), amit Somogyi (2018) modellezési eredményei is igazolnak, azaz az évszázad végére a klímaváltozás hatására nagyon jelentős mortalitás-növekedés, fafajösszetétel-változás és fanövekedéscsökkenés következhet be. A klíma megváltozásának hatásait (a záródás, a várható mortalitás, a fakészlet és a fafaj-összetétel stb. változását) részletes, geodéziailag referált térinformatikai adatbázisokból kiinduló prognózisok segítségével kellene vizsgálni (Illés 2018, Kottek 2016 és 2018). A Magyarország területére vonatkozó klíma-elörejelzésekből (Bartholy et al 2007, Gálos et al 2015) levezethető, hogy a jövőben olyan termőhelytípus-változatok megjelenésével is számolnunk kell, amelyek eddig hazánkban nem fordultak elő (Bidló \& Horváth 2018). A társulások fafajainak eltérő érzékenységéből adódó dinamika szintén olyan társulásokat tehet potenciálissá, melyek egzakt jellemzése jelenleg még előttünk áll (Bartha et al 2018). A hazai erdészeti kutatás és gyakorlat egyik nagy feladata, hogy fafajválasztási javaslatokat tudjon adni az újonnan kialakuló termőhelyekre is (Bidló \& Horváth 2018).

Az éghajlati elemek közül a termőhely klímatényezőjének jellemzésére a klasszikus erdészeti termőhely-tipológiában a légnedvességet találták a legalkalmasabbnak. Járó (1972) az erdészeti klímakategóriákat az átlagos júliusi 14 órai légnedvesség értékéhez kötötte, azonban e definíció szerint napjainkban már nem gyüjtenek adatokat (a hivatalos meteorológiai észlelési időpontok megváltoztak). Többek között ezért jelentős az erdészeti szárazsági mutató (FAl) (Führer 2010, 2017, 2018, Führer et al 2011, 2017b), illetve más, könnyen elérhető meteorológiai adatokra támaszkodó klímaindex, és ezért javasolható meteorológiai adatokra támaszkodó klímaindexek bevezetése az erdőtervezői gyakorlatba, mert kiküszöbölhetővé tennék a klímabesorolás szubjektivitását, és adatolhatóvá (sőt: előre jelezhetővé) tennék a klíma jellemzését (Führer et al 2017a).

A meteorológiai méréseken alapuló klímaindexek lokális léptékben, pl. erdőrészletek szintjén történő alkalmazásának korlátja, hogy az indexek vagy alapadataik interpolálásával legfeljebb kb. 2-5 km-es felbontásban (megengedőbb álláspontok szerint $1 \mathrm{~km}$-es felbontásban, lásd pl. Horváth \& Mátyás 2016 és Illés 2018) lehet korrekt eredményeket kapni; továbbá $a z$, hogy meteorológia észlelések igen ritkán történnek erdőben.

Ezzel szemben a hagyományos terepi klímabesorolás jobb térbeli felbontásban áll rendelkezésre: ugyan nem meteorológiai adatok alapján, de azt erdőrészletenként adják meg, figyelembe véve a domborzat módosító hatásait is (kitettség, lejfok stb.). Az egyes erdőrészletek klímabesorolásának megállapitása a körzeti erdőtervezéskor történik. A besorolás a gyakorlatban a 14 órás légnedvesség mérése helyett szakértői becslést jelent, és a növényzet összetételére, különösen a klímajelző fás- és lágyszárúak jelenlétére, valamint a domborzat, a tengerszint feletti magasság hatásainak ismeretére támaszkodik (Járó 1972). A lényeg a növényzeti indikáció (vagy a fitométer-koncepció), ami a klímajelző fajok elterjedését, vagy nem természetes erdőtársulás esetén a feltételezett természetes zonális társulás fafajait veszi alapul. Az erdészeti gyakorlatban a klíma jellemzésénél tehát egyelöre nem 
tudunk eltekinteni a hagyományos, szakértői becslésen alapuló módszertől sem, bár ez a módszer több-kevesebb szubjektivitással terhelt.

Felvetődik, hogy ha az OEA-ban az erdők klíma szerint besorolása jó térbeli felbontásban rendelkezésre áll, mely besorolás minden szubjektivitásával együtt igen nagy számú és évtizedek óta elvileg változatlan metodikájú terepi megfigyelésen alapul - akkor igazolható-e a klíma megváltozása az OEA klíma-kategóriái segítségével?

\section{ADAT ÉS MÓDSZER}

Az OEA térképi nyilvántartása 2006-tól vizsgálható, azóta létezik országosan egységes, digitalizált formában. A korábbi évjáratok vagy nem teljesek, vagy a térinformatikai adatok nem megfelelő minőségüek.

A körzeti erdőtervezés 10 éves visszatérési idővel dolgozik, ami azt jelenti, hogy ugyan azon az erdőterületen (kisebb eltérésekkel) 10 évenként történik új terepi adatgyüjtés. Az OEA 2006-ra érvényesnek tekintett ún. statisztikai állapota, mely a térinformatikai feldolgozás szempontjából a lehetséges legkorábbi kiinduló állapot, így zömmel 1995 és 2005 közötti adatfelvételeket tartalmaz. Ugyanígy a 10 évvel későbbi, 2016-os statisztikai állapot 2005-2015 közöttieket. Vizsgálatunkban ezt a két periódust hasonlítottuk össze, és a továbbiakban 2006-os, illetve 2016-os állapotként hivatkozunk rájuk.

A két 10 éves periódus a klímatudományban szokásos és elfogadott 20-30 éves periódusoknál kétségtelenül sokkal rövidebb, de sajnos a kívánt területi felbontás mellett - az erdőrészletek méreteivel összevethető részletességet céloztunk meg - hosszabb periódusokat vizsgálni nem látszik megoldhatónak.

A klíma-kategóriák nagy területü összehasonlítása és két periódus között észlelhető lokális változásainak leírása feltételezné, hogy a két periódusban az erdörészletek megfeleltethetők egymásnak, ez azonban az OEA-ban sajnos nem áll fenn teljes körüen. Az erdörészleteknek élet-története van, azaz megosztják, összevonják őket, a határaik elmozdulnak, s néha teljesen átalakulnak, emiatt az összerendelés nem minden esetben adható meg. A problémán a rácsos mintavétel koncepciója segített, ami egyfajta, a raszteres adatszerkezethez hasonló megoldás. Fektessünk a térképre egy sürü (100×100 méteres) négyzetes rácshálót, és minden rácsponthoz mindkét adattári állapotra vonatkozóan (tehát egy teljes erdőtervezési ciklust átfogva) rendeljük hozzá az ott lévő erdőrészletet illetve annak klímabesorolását. Az egyes rácspontok hiba nélkül egymáshoz rendelhetők és 1 hektár felbontással megadhatók a klímakategóriák közti átmenetek. A módszer hátránya, hogy kissé felülbecsli a változásokat, mert a térképi pontatlanságok korrekciója miatt (pl. amikor az erdőrészlet határai 20-50 méterrel arrább kerülnek, de a természetben az erdőrészlet geometriája valójában nem változik) a határok módosulásai hibás új-erdő és megszűnt-erdő rácspontokat eredményeznek, amik a valóságban nincsenek. 
Az OEA-ban 2006-2008 között nagyon sok invalid poligon is szerepelt az erdészeti térképeken, ezek kisebb-nagyobb technikai hibák, pl. amikor az erdőrészlet-határokat leíró koordináta-párok lánca nem záródik - de a térinformatikai műveleteket sajnos megakadályozzák. Ezért az invalid erdőrészletek alakzatait azonosítani kellett a már javított és teljesen valid 2009-es állapotban. A korrekció kb. 40 ezer hektárt érint, és becslésünk szerint szintén hordoz 3-4 ezer hektár bizonytalanságot.

A módszer nagy előnye, hogy a rácsháló, mint térbeli mintavétel alkalmazhatóvá teszi a standard statisztikai kiértékeléseket, mert a szabályos hálóban elhelyezkedő rácspontok független, egyenlő súlyú észleléseknek tekinthetők.

\section{EREDMÉNYEK ÉS ÉRTÉKELÉSÜK}

A klímát sokáig szinte változatlan és stabil termőhelyi tényezőnek tartották. A klíma változásának megitélése elsősorban abban áll, hogy az mégis milyen gyorsan változik meg? A klímabesorolás egy nem-változó klímában meglehetősen konzervatív természetü kellene legyen, azaz az erdők többségénél 10 év alatt egyáltalán nem lenne szabad módosulnia. Ezzel szemben a 2006-ban és 2016-ban egyaránt erdörészletekre eső rácspontok 5,4\%-ában (1.773.237 ha -1.677 .838 ha $=95.399$ ha; lásd az 1. táblázatot) megváltozott. A változás sebességét szemléltetendő tekintsünk egy rövid gondolatkísérletet, melyben ha a klímabesorolások változásának sebességét állandónak feltételeznénk és durva leegyszerüsitéssel lineárisan extrapolálnánk, akkor azt kapnánk, hogy nagyjából 200 év alatt, azaz néhány vágásforduló alatt a teljes erdőterületen megváltozna a klímabesorolás, ami növényföldrajzi léptékben elképesztően gyorsnak hat. Ehhez hozzá kell tenni, hogy a két időpont közt észlelt erdő-megszünések egy része is összefüggésbe hozható a klíma megváltozásával.

Az elmozdulások iránya figyelmeztető, mert a változások általában kedvezőtlenek (1. táblázat).

A 2006-os állapotban még nem-erdö, 2016-ban már erdő (új) rácspontok között legnagyobb területü az ESZTY klíma (az országos eloszlásban a területfoglalása $25 \%$ körüli, ehhez képest az új erdők közt 37\%). Tehát az új erdőket is szárazabb körülmények közt hoztuk létre, föleg azért, mert az erdőtelepítésekhez ebben a klímában áll rendelkezésre a legtöbb, mezőgazdasági művelés számára gazdaságtalan terület.

A 2006-ban bükkös klímába sorolt erdők 7,3\%-a sorolódott át az eggyel kedvezőtlenebb GY-T-es klímába. A 2006-ban GY-T-es klímába sorolt erdők 5,2\%-a sorolódott át 10 év alatt a kedvezőtlenebb KTT-CS klímába. A 2006-ban KTT-CS klíma érdekes módon nagyobb mértékben mozdult a kedvezőbb GY-T felé, mint az ESZTY felé.

A 2006-ban az ESZTY klímába tartozó rácspontok meglehetősen nagy része (8,7\%-a) nem volt fellelhető a 2016-os térképen. Ez arra enged következtetni, hogy az erdőgazdálkodás kivonul a határ-termőhelyekröl, feladja azok újraerdősitését, vagy friss erdőtelepitések esetén a telepítés nem jut el a befejezésig. A 2006-ban még erdő, de 2016-ra eltünt, már nem-erdő rácspontok 44\%-a az ESZTY klímába tartozott, azaz e klíma-kategóriába tartozó 
faállományok nagyobb eséllyel szűnnek meg a többi klíma-kategóriába tartozó faállományoknál.

1. táblázat: Az egyes klímakategóriába eső erdőterület változásai az Országos Erdőállomány Adattárban a 2006-os és a 2016-os állapot között. A táblázat soraiban a 2006-os állapot, az oszlopokban a 2016-os állapot terület-eloszlása van feltüntetve. A táblázat cellái a klímakategóriák közti átmeneteket jelölik. Pl. 2006-ban

161.826 ha tartozott a bükkös klímába (jobb felsö cella), melyből 2016-ra 1.965 ha kikerült az Adattárból, minimális terület ment át az ESZTY illetve a KTT-CS kategóriába, 11.789 hektárból lett GY-T, és 148 ezer ha maradt bükkös.

Table 1: Changes in the climatic classification of forest areas in the National Forestry Database in the time period 2006-2016. In the rows of the table is represented the 2006 state of the climate distribution. In the columns the 2016 state is represented. The cells represent the shifts between the climatic classifications.

E.g. in 2006 the area under "beech" climate was 161,826 hectare (top right corner), from this area 1965 hectare has been transferred to a non-forest land use category, very small areas have been reclassified as "forest steppe" and "sessile oak - Turkey oak" climate, while 11,242 hectare has been reclassified as "hornbeam and oak" climate, and 147,806 hectare remained under the same "beech" category.

\begin{tabular}{|c|c|c|c|c|c|c|c|}
\hline \multicolumn{7}{|c|}{ Erdőrészletekre eső rácspontok száma klímakategóriák szerint (hektár) } & \\
\hline \multirow{2}{*}{ 2006-ban } & \multicolumn{6}{|c|}{ 2016-ban } & \\
\hline & $\mathrm{B}$ & GY-T & KTT-CS & ESZTY & nem erdő & összesen & \\
\hline $\mathrm{B}$ & 147.806 & $2 / 11.789$ & $\angle L 239$ & $2 / 2 \pi$ & 1.965 & 161.826 & \\
\hline GY-T & 11.242 & 646.190 & 37.015 & $2 4 2 \longdiv { 1 1 }$ & 20.483 & 714.941 & \\
\hline KTT-CS & $2 \longdiv { 2 4 0 }$ & 23.445 & 458.896 & 286.247 & 28.968 & 517.796 & \\
\hline ESZTY & 8770 & 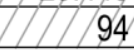 & 5.050 & 424.946 & 41.222 & 471.312 & \\
\hline nem erdö & 3.800 & 43.827 & 57.247 & 61.169 & - & 166.043 & \\
\hline összesen & 163.088 & 725.345 & 558.447 & 492.400 & 92.638 & & \\
\hline & $\begin{array}{l}\text { áltozatlan } \\
\text { ímájú } \\
677.838\end{array}$ & $\begin{array}{l}\text { erdö m } \\
\text { idöpon } \\
1,773 .\end{array}$ & $\begin{array}{l}\text { indkét } \\
\text { ban } \\
37\end{array}$ & $\begin{array}{l}10 \text { év alatt } \\
\text { megszünt } \\
\text { erdő }\end{array}$ & $\begin{array}{l}10 \text { év } \\
\text { keletk } \\
\text { új erd }\end{array}$ & $\begin{array}{l}\text { alatt } \\
\text { ezett }\end{array}$ & $\begin{array}{l}2006-0 s \\
\text { erdöterület } \\
1.865 .848\end{array}$ \\
\hline
\end{tabular}

Valóban megváltozott-e a klíma a két periódus között? A kérdést a két periódusban tapasztalható területi eloszlások statisztikai próbááával lehet értékelni. A klímák területi eloszlásai teljesítik a khi2-próba feltételeit, habár a minták mérete meglehetősen nagy, és ilyenkor az elsőfajú hiba elkövetésének veszélye fokozott. A mindkét időpontban erdőterületre eső rácspontok (1.773.237 ha) klíma szerinti eloszlásait tekintve a 2006-os és 2016-os állapot szignifikánsan különbözőnek mutatkozik $\left(\mathrm{khi}^{2}=278,84 ; \mathrm{df}=3\right.$; $p<0,000001)$. A megváltozott klímájú rácspontok eloszlása, a megszünt erdőterületek és az újonnan keletkezett erdők klíma szerinti eloszlása is mind-mind szignifikánsan különbözik a klímakategóriák egyenletes eloszlásától, a klímák trendszerű eltolódása tehát ezeken a részhalmazokon is igazolható. 
A klímák egymásba alakulását, az átalakulás trendjeit és földrajzi eloszlását 1-5. ábrák térképein mutatjuk be. A térképeken az egyes pixelek $1 \times 1 \mathrm{~km}$-es területnek felelnek meg, és a 100×100 méteres hálón mért 10×10 darab elemi rácspont 2016-os besorolásának leggyakoribb kategóriáját (módusz) jelzik, tehát a klímabesorolás megváltozásának legjellemzőbb irányát (vagy meg-nem-változását) mutatják. Nem mennyiségi mutatók és nem jelzik az erdősültséget sem. PI. a pixel színe ugyan úgy piros, ha egy nagy erdősültségü területen a lehetséges 100 darab elemi rácspontból a legtöbb az ESZTY kategóriába esett 2016-ban; és piros akkor is, ha a lehetséges 100-ból csak egyetlen rácsponton volt erdő 2016-ban, ám az történetesen ESZTY besorolású volt.

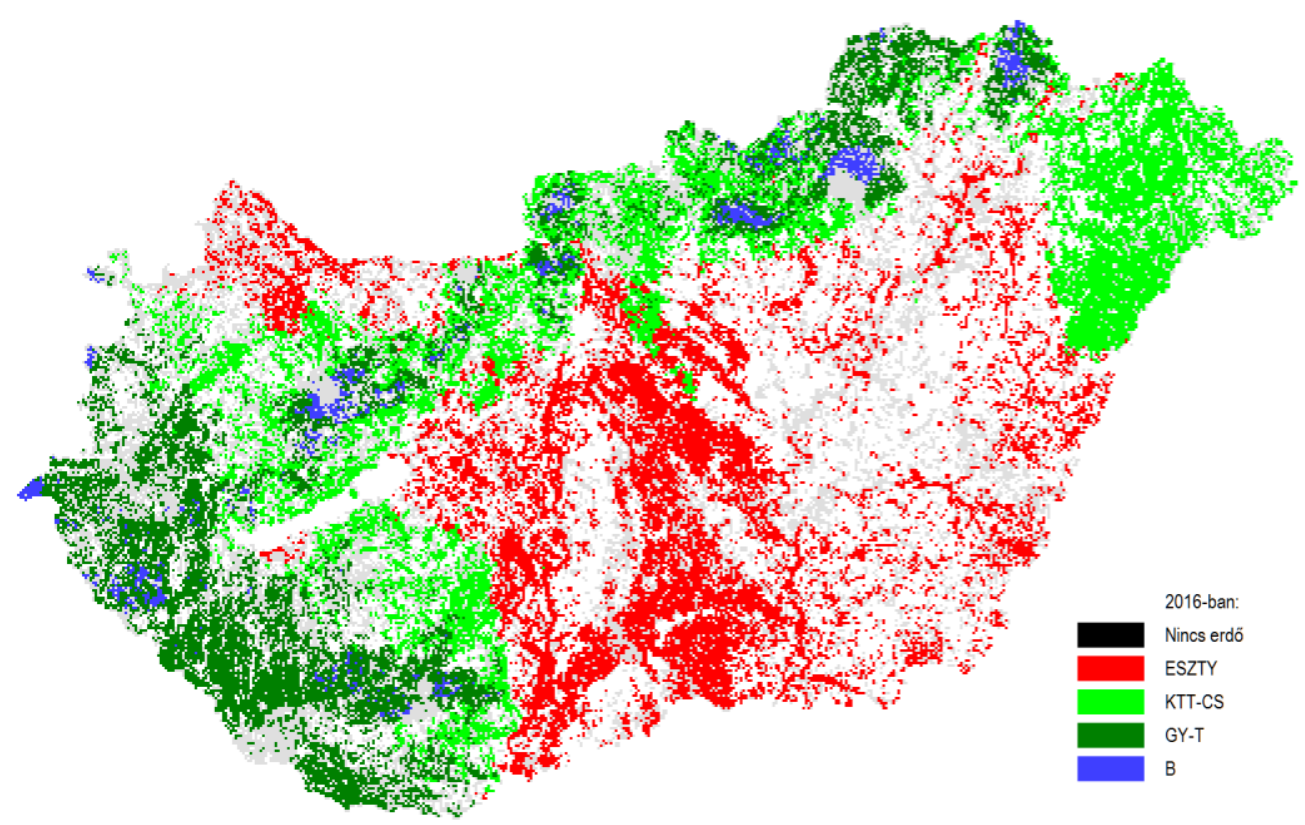

1. ábra: 2006 és 2016 között nyilvántartásba vett új erdőterületek klíma szerinti besorolása az Országos Erdőállomány Adattárban.

Figure 1: Climate categories of new forests established between 2006 and 2016 according to the National Forestry Database. 


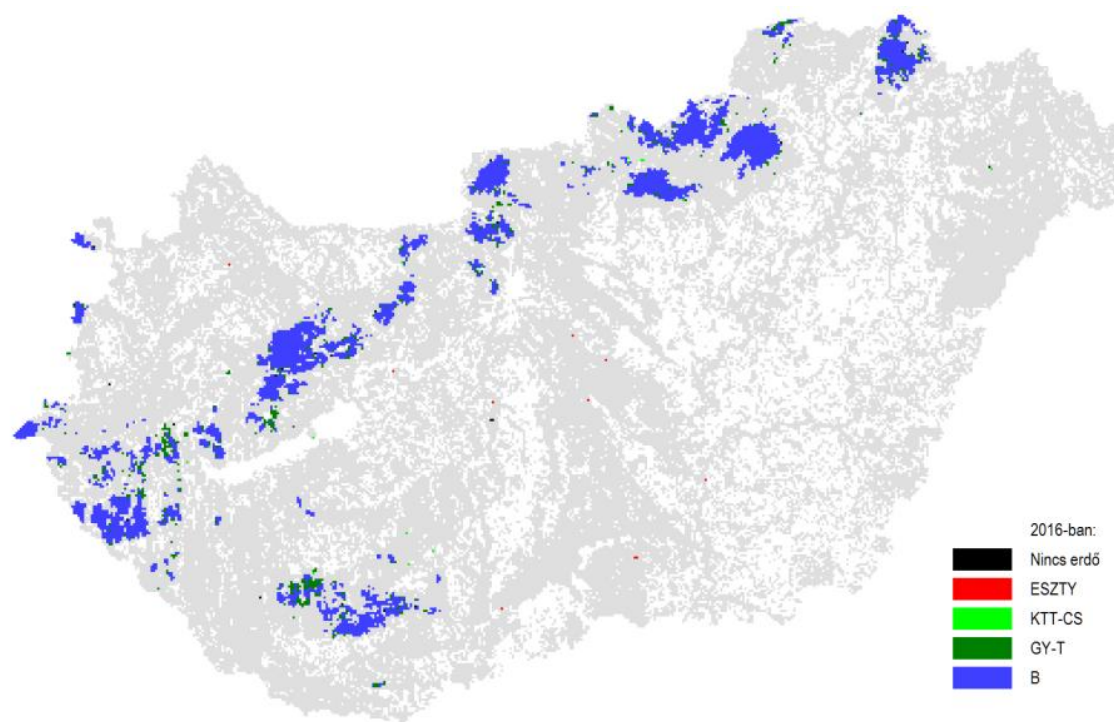

2. ábra: 2006-os állapotban bükkös klíma-besorolású területek jellemző klíma szerinti besorolása az Országos Erdőállomány Adattár 2016. évi állapotában.

Figure 2: Climate classification of areas in 2016 which were macroclimatically suitable for beech in 2006 according to the National Forestry Database.

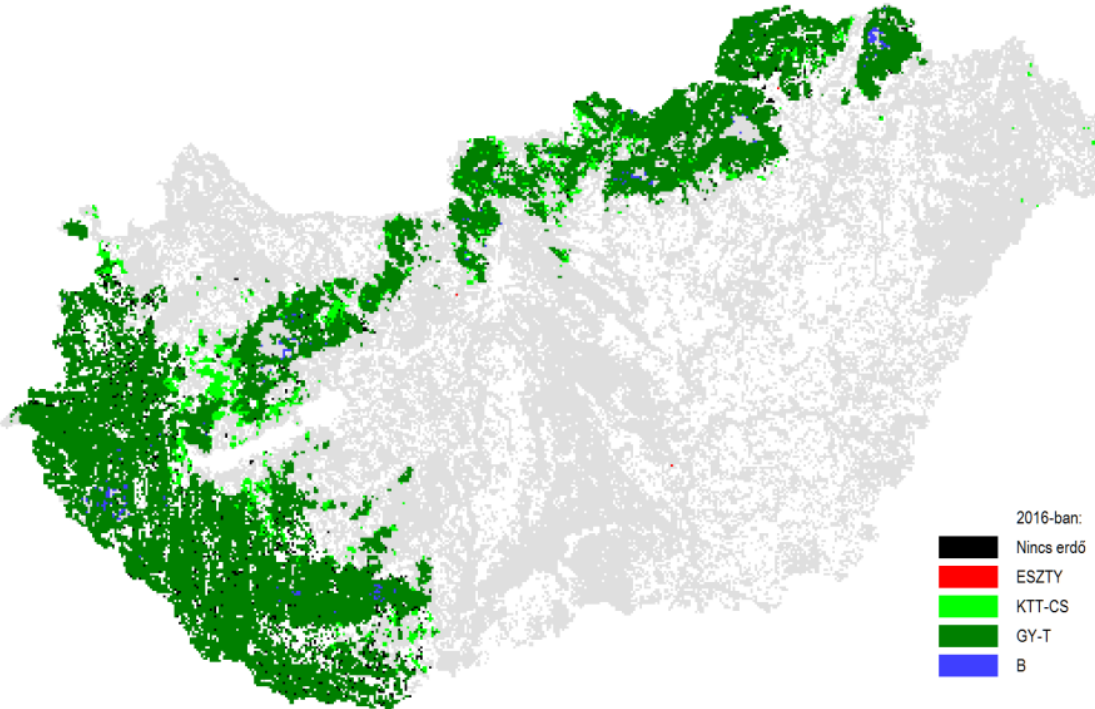

3. ábra: 2006-os állapotban gyertyános tölgyes klíma-besorolású területek jellemző klíma szerinti besorolása az Országos Erdőállomány Adattár 2016. évi állapotában.

Figure 3: Climate classification of areas in 2016 which were macroclimatically suitable for hornbeam and oak in 2006 according to the National Forestry Database. 


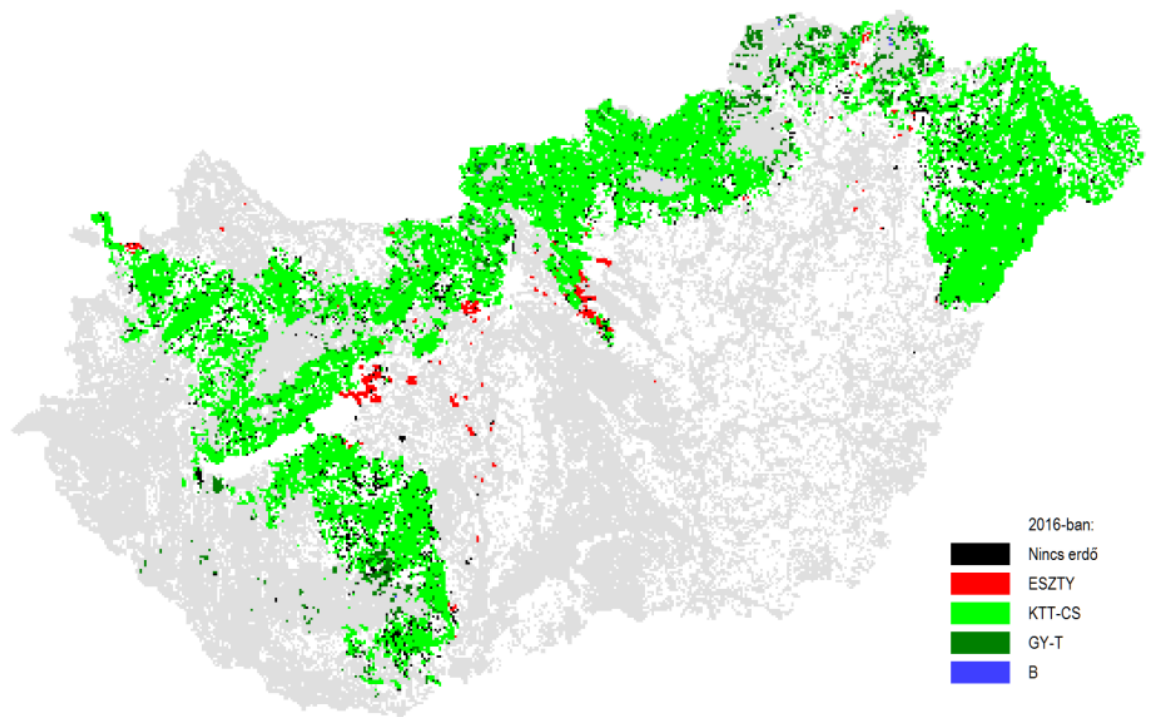

4. ábra: 2006-os állapotban kocsánytalan tölgyes-cser klíma-besorolású területek jellemző klíma szerinti besorolása az Országos Erdoállomány Adattár 2016. évi állapotában.

Figure 4: Climate classification of areas in 2016 which were macroclimatically suitable for sessile oak and Turkey oak in 2006 according to the National Forestry Database.

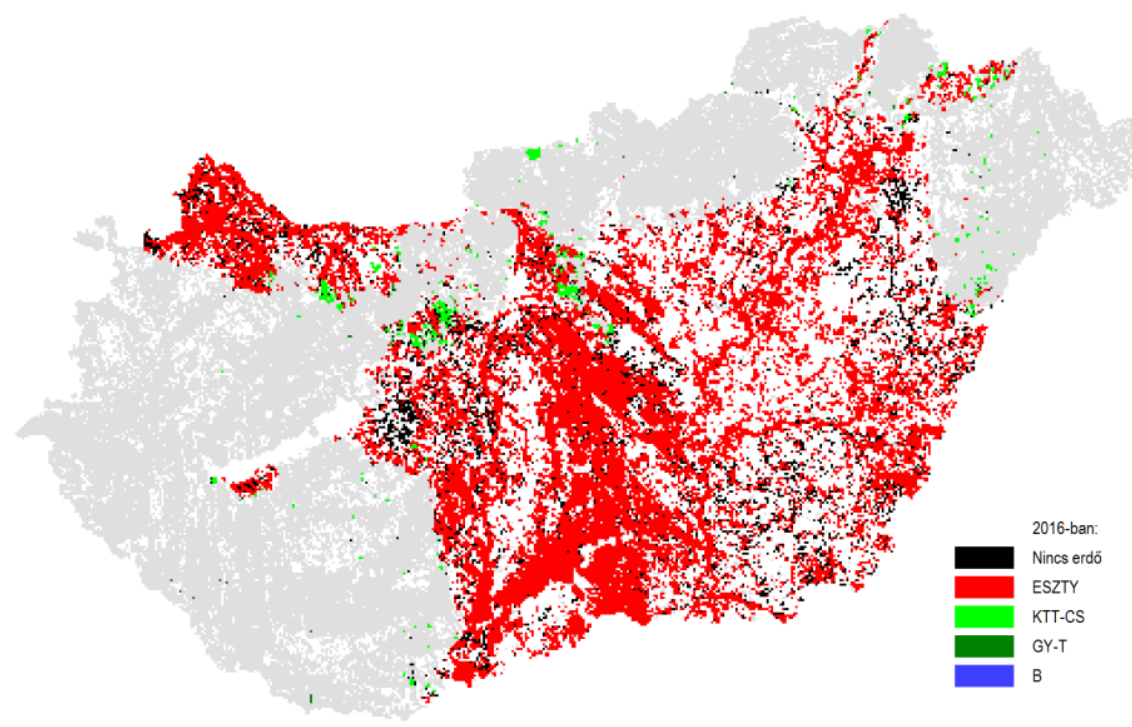

5. ábra: 2006-os állapotban erdőssztyepp klíma-besorolású területek jellemző klíma szerinti besorolása az Országos Erdőállomány Adattár 2016. évi állapotában.

Figure 5: Climate classification of areas in 2016 which were classified as forest steppe in 2006 according to the National Forestry Database. 


\section{ÖSSZEFOGLALÁS}

Adósak maradtunk a tapasztalt jelenségek okainak magyarázatával: további, részletesebb vizsgálatok szükségesek annak megállapítására, hogy a klíma-besorolás megváltoztatása mögött az egyes rácspontokban és erdőrészletekben mi áll. Egyelöre nincs válaszunk arra, hogy pl. konkrét erdőfelújitási problémák adták-e a kezdőlökéseket; vagy az értő szakközönség elé tárt klímakutatási eredmények (lásd pl. Bondor \& Frank 2010, és legutóbb Mátyás et al 2017) illetve a témában hosszú ideje folyó viták (többek között pl. Gálhidy \& Tímár 2011, Mátyás 2011) csapódtak-e le az igazgatási adminisztrációban, a tudományos közösség eredményeinek elfogadásaként, arra reflektálva - utóbbi esetben ugyanis az OEA klímakategóriáinak változásai nem független megfigyelések és objektíven nem igazolnak semmilyen változást.

Célszerü lenne részletesebben elemezni, hogy a klímakategóriák közti átsorolások területi eloszlása hogyan függ össze a helyben mérhető meteorológiai paraméterekkel és az ezekböl levezetett klímaindexek adott időszakban kimutatható állapotával és változásával, hiszen tudjuk, hogy az OEA klímabesorolásai és a klímaindexek több erdészeti tájban jelentős eltérést mutatnak (Führer 2018).

Azonban vizsgálatunk eredményei az okok ismerete nélkül is rámutatnak arra, hogy az OEA-ban használt klímabesorolás változásai a 2006-os és a 2016-os statisztikai állapot közötti 10 éves időtartamban szignifikánsak, a változások a térképen kirajzolódnak, a klíma megváltozásának ténye tehát az OEA adataiból is igazolható.

\section{KÖSZÖNETNYILVÁNÍTÁS}

Köszönettel tartozunk elsősorban az erdészeti igazgatás erdőtervezői kollektívájának a sanyarú körülmények közt is rendületlen adatgyüjtési munkáért, mely alapot adott a kutatáshoz; Wisnovszky Károly igazgató úrnak, mert lehetővé tette a vizsgálatot; illetve Dr. Tobisch Tamásnak és Dr. Csanády Viktóriának a statisztikai kiértékelésben nyújtott ötletekért és támogatásért.

Jelen publikáció az „EFOP-3.4.3-16-00022 QUALITAS Minőségi felsőoktatás fejlesztés Sopronban, Szombathelyen és Tatán" című projekt támogatásával valósult meg.

\section{FELHASZNÁLT IRODALOM}

Bartha D., Berki I., Lengyel A., Rasztovits E., Tiborcz V. \& Zagyvai G. 2018: Erdőtársulások és fafajaik átrendeződési lehetőségei a változó klímában. Erdészettudományi Közlemények 8(1): 163-195. DOI: 10.17164/EK.2018.011

Bartholy J., Pongrácz R. \& Gelybó Gy. 2007: Regional climate change expected in Hungary for 2071-2100. Applied Ecology and Environmental Research 5(1): 1-17. DOI: 10.15666/aeer/0501_001017 
Berki I. 2017: Szárazodás befolyásolta kigyérülés a kocsánytalan tölgy példáján. (A klímaváltozáshoz alkalmazkodó erdőgazdálkodás kihívásai - I.) Erdészeti Lapok 152(4): 105-106.

Berki I., Móricz N., Rasztovits E., Gulyás K., Garamszegi B., Horváth A., et al. 2018: Fapusztulás és gyorsuló növekedés kocsánytalan tölgyeseinkben. Erdészettudományi Közlemények 8(1): 119-130. DOI: 10.17164/EK.2018.008

Berki I., Rasztovics E. \& Móricz N. 2014: Erdőállományok egészségi állapotának értékelése - egy új megközelítés. Erdészettudományi Közlemények 4(2): 149-155.

Berki I., Rasztovics E., Móricz N. \& Kolozs L. 2016: The Role of Tree Mortality in Vitality Assessment of Sessile Oak Forests. South-east European forestry 7(2): 91-97. DOI: 10.15177/seefor.16-14

Bidló A. \& Horváth A. 2018: Talajok szerepe a klímaváltozásban. Erdészettudományi Közlemények 8(1): 57 71. DOI: $10.17164 / E K .2018 .004$

Bondor A. \& Frank N. 2010: Erdőgazdálkodás a klímaváltozás tükrében. Erdészeti Lapok 145(12): 410-415.

Czúcz B., Gálhidy L. \& Mátyás Cs. 2013: A bükk és a kocsánytalan tölgy elterjedésének szárazsági határa. Erdészettudományi Közlemények 3(1): 39-53.

Csóka Gy. \& Hirka A. 2017: A változások jelei. (A klímaváltozáshoz alkalmazkodó erdőgazdálkodás kihívásai - I.) Erdészeti Lapok 152(4): 104-105.

Csóka Gy., Koltay A., Hirka A. \& Janik G. 2007: Az aszályosság hatása kocsánytalan tölgyeseink és bükköseink egészségi állapotára. In: Mátyás Cs. \& Vig P. (eds): Erdő és Klíma V. Nyugat-magyarországi Egyetem, Sopron, 229-239.

Csóka Gy., Koltay A., Hirka A. \& Janik G. 2009: Az aszályosság hatása kocsánytalan tölgyeseink és bükköseink egészségi állapotára. Klíma-21 Füzetek 57: 64-73.

Führer E. 2010: A fák növekedése és a klíma. Klíma-21 Füzetek 61: 98-107.

Führer E. 2017a: Az erdészeti klímaosztályok új lehatárolása öko-fiziológiai alapon. (A klímaváltozáshoz alkalmazkodó erdőgazdálkodás kihívásai - III.) Erdészeti Lapok 152(6): 173-174.

Führer E. (ed) 2017b: Magyarország erdészeti tájai, I. Nagyalföld erdészeti tájcsoport és II. Északi-középhegység erdészeti tájcsoport. NÉBIH, Budapest.

Führer E. 2018: A klímaértékelés erdészeti vonatkozásai. Erdészettudományi Közlemények 8(1): 27-42. DOI: 10.17164/EK.2018.002

Führer E., Horváth L., Jagodics A., Machon A. \& Szabados I. 2011: Application of a new aridity index in Hungarian forestry practice. Időjárás 115(3): 103-118.

Führer E., Jagodics A., Juhász I., Marosi Gy. \& Horváth L. 2013: Ecological and economical impacts of climate change on Hungarian forestry practice. Időjárás 117(2): 159-174.

Führer E., Gálos B., Rasztovits E., Jagodics A. \& Mátyás Cs. 2017a: Erdészeti klímaosztályok területének várható változása. (A klímaváltozáshoz alkalmazkodó erdőgazdálkodás kihívásai - III.) Erdészeti Lapok 152(6): 174-177.

Führer E., Horváth L., Móring A., Pödör Z. \& Jagodics A. 2017b: Az erdészeti szárazsági mutató (FAl) segítségével lehatárolt erdészeti klímaosztályok/klímakategóriák jellemzése. (A klímaváltozáshoz alkalmazkodó erdőgazdálkodás kihívásai - IV.) Erdészeti Lapok 152(9): 270-272.

Gálhidy L. \& Tímár G. 2011: Őshonos fafajú erdeink a klímaváltozás szoríásában? Erdészeti Lapok 146(2): 38-40.

Gálos B., Führer E., Czimber K., Gulyás K., Bidló A., Hänsler A. et al. 2015: Climatic threats determining future adaptive forest management - a case study of Zala County. Időjárás 119(4): 425-441.

Gálos B. \& Führer E. 2018: A klíma erdészeti célú elörevetítése. Erdészettudományi Közlemények 8(1): 4355. DOI: $10.17164 /$ EK.2018.003

Hirka A. (eds) 2017: A 2016. évi biotikus és abiotikus erdőgazdasági károk, valamint a 2017-ben várható kárositások. NAIK Erdészeti Tudományos Intézet, NÉBIH Erdészeti Igazgatóság, Budapest.

Hirka A., Pödör Z., Garamszegi B. \& Csóka Gy. 2018: A magyarországi erdei aszálykárok fél évszázados trendjei (1962-2011). Erdészettudományi Közlemények 8(1): 11-25. DOI: 10.17164/EK.2018.001 
Honnay O., Verheyen K., Butaye J., Jacquemyn H., Bossuyt B. \& Hermy M. 2002: Possible effects of habitat fragmentation and climate change on the range of forest plant species. Ecology Letters 5: 525-530. DOI: 10.1046/j.1461-0248.2002.00346.x

Horváth A. \& Mátyás Cs. 2016: The Decline of Vitality Caused by Increasing Drought in a Beech Provenance Trial Predicted by Juvenile Growth. South-east European forestry 7(1): 21-28. DOI: 10.15177/seefor.16$\underline{06}$

Illés G. 2018: A klímaváltozás nyomán bekövetkező fatermésváltozás becslése a kocsánytalan tölgy példáján. Erdészettudományi Közlemények 8(1): 105-118. DOI: 10.17164/EK.2018.007

Járó Z. 1972: Az erdészeti termőhely-értékelés rendszere. In. Danszky I. (ed): Erdőművelés I. Mezőgazdasági Könyvkiadó, Budapest, 47-256.

Kottek P. 2016: Országos Erdőállomány Prognózis $\rightarrow$ 2050. Modell: Divine Axe Superhero, DAS v11k. A Soproni Egyetem Erdőmérnöki Karának Tudományos Konferenciája, 2016. október, poszter.

Kottek P. 2018: A KLM-szcenárió koncepciója. Soproni Egyetem, PhD éves beszámoló előadás, 2018. június.

Lindner M., Fitzgerald J.B., Zimmermann N.E., Reyer C., Delzon S., Maaten E., et al. 2014: Climate change and European forests: What do we know, what are the uncertainties, and what are the implications for forest management? Journal of Environmental Management 146: 69-83. DOI: 10.1016/j.jenvman.2014.07.030

Mátyás Cs. 2010: Forecasts needed for retreating forests (opinion). Nature 464: 1271. DOI: 10.1038/4641271a

Mátyás Cs. 2011: Különóra a klímaváltozásról, egykori tanítványaimnak. Erdészeti Lapok 146(3): 75-76.

Mátyás Cs., Führer E., Berki I., Csóka Gy., Drüszler Á., Lakatos F., et al. 2010a: Erdők a szárazsági határon. Klíma-21 Füzetek 61: 84-97.

Mátyás Cs., Nagy L. \& Ujváriné J.É. 2009: Klimatikus stressz és a fafajok genetikai válaszreakciója az elterjedés szárazsági határán: elemzés és elörejelzés. Klíma-21 Füzetek 56: 57-65.

Mátyás Cs., Berki I., Czúcz B., Gálos B., Móricz N. \& Rasztovits E. 2010b: Future of beech in Southeast Europe from the perspective of evolutionary ecology. Acta Silvatica \& Lignaria Hungarica 6: 91-110.

Mátyás Cs., Csóka Gy., Hirka A. \& Berki I. 2017: A klímaváltozáshoz alkalmazkodó erdőgazdálkodás kihívásai - I. Erdészeti Lapok 152(4): 102-106.

Milad M., Schaich H., Bürgi M., Konold W. 2011: Climate change and nature conservation in Central European forests: A review of consequences, concepts and challenges. Forest Ecology and Management 261(4): 829-843. DOI: $10.1016 /$ j.foreco.2010.10.038

Sánchez-Salguero R., Navarro-Cerrillo R.M., Swetnam T.W. \& Zavala M.A. 2012: Is drought the main decline factor at the rear edge of Europe? The case of southern Iberian pine plantations. Forest Ecology and Management 271: 158-169. DOI: 10.1016/i.foreco.2012.01.040

Somogyi Z. 2018: A klímaváltozás miatti fapusztulás tovább gyorsíthatja a klímaváltozást. Erdészettudományi Közlemények 8(1): 211-226. DOI: 10.17164/EK.2018.013

Thurm E.A., Hernandez L., Baltensweiler A., Ayan S., Rasztovits E., Bielak K., et al. 2018: Alternative tree species under climate warming in managed European forests. Forest Ecology and Management 430: 485497. DOI: $10.1016 /$ j.foreco.2018.08.028

\section{ON-LINE MEGJELENT IRODALOM}

Székely B. 2010: Statisztikai hipotézisvizsgálat (elöadásvázlat). Letöltve: 2019. január 1.

http://math.bme.hu/ szbalazs/oktatas/sztoch_vill/het_6_hipotezis.pdf

Érkezett: 2019. január 6.

Közlésre elfogadva: 2019. június 25. 